\title{
Effect of Soybean Varieties and Nitrogen Fertilizer Rates on Yield, Yield Components and Productivity of Associated Crops Under Maize/Soybean Intercropping at Mechara, Eastern Ethiopia
}

\author{
Wondimu Bekele ${ }^{1, *}$, Ketema Belete ${ }^{2}$, Tamado Tana ${ }^{2}$ \\ ${ }^{1}$ Oromia Agricultural Research Institute, Mechara Agricultural Research Center, West Hararghe Zone, Mechara, Ethiopia \\ ${ }^{2}$ College of Agriculture and Environmental Science, Department of Plant Science, Haramaya University, Dire Dawa, Ethiopia
}

\section{Email address:}

wondubekele@gmail.com (W. Bekele)

\section{To cite this article:}

Wondimu Bekele, Ketema Belete, Tamado Tana. Effect of Soybean Varieties and Nitrogen Fertilizer Rates on Yield, Yield Components and Productivity of Associated Crops Under Maize/Soybean Intercropping at Mechara, Eastern Ethiopia. Agriculture, Forestry and Fisheries. Vol. 5, No. 1, 2016, pp. 1-7. doi: 10.11648/j.aff.20160501.11

\begin{abstract}
Due to decreasing land units and decline in soil fertility integrating soybean in to the maize production system is a viable option for increasing productivity and protein source. In view of this, field experiment was conducted during 2012 at Mechara Agricultural Research Center with theobjectives of identifying best compatible combinations of maize with soybean varieties and $\mathrm{N}$ rates for maximum yield and yield components of the associated cropsand productivity of intercropping system. Three varieties of soybean (Awasa-95, Cocker-240 and Crowford) were intercropped with early maturing maize variety Melkasa-2 with three rates of nitrogen $\left(32,64\right.$ and $\left.96 \mathrm{~kg} \mathrm{~N} \mathrm{ha}^{-1}\right)$. The experiment waslaid out in factorial arrangement in randomized complete block design in three replications. Highest maize grain yield $\left(2196 \mathrm{~kg} \mathrm{ha}^{-1}\right)$ was obtained from soybean variety Crowford and $32 \mathrm{~kg} \mathrm{~N} \mathrm{ha}^{-1}$ and lowest yield $\left(1352 \mathrm{~kg} \mathrm{ha}^{-1}\right)$ was recorded from maize intercropped with soybean variety Awasa-95 at $96 \mathrm{~kg} \mathrm{~N} \mathrm{ha}^{-1}$. The grain yield of intercropped soybean was increased from $586 \mathrm{~kg} \mathrm{ha}^{-1}$ to $842 \mathrm{~kg} \mathrm{ha}^{-1}$ as the nitrogen rates increased from $32 \mathrm{~kg} \mathrm{~N} \mathrm{ha}^{-1}$ to $96 \mathrm{~kg} \mathrm{~N} \mathrm{ha}^{-1}$. The higheist LER (1.10) was obtained from maize intercropped with soybean variety Crowford and lowest LER (1.08) was from maize intercropped with variety Cocker-240 due to main effects of soybean varieties while due to main effects of $\mathrm{N}$, the highest (1.16) and the lowest (1.1) LER were obtained from higher rate of nitrogen $\left(96 \mathrm{~kg} \mathrm{~N} \mathrm{ha}^{-1}\right)$ and lowest rate of nitrogen $\left(32 \mathrm{~kg} \mathrm{~N} \mathrm{ha}^{-1}\right)$, respectively. On the other hand, the highest Gross Monetary Value (17315 Birr ha $\left.{ }^{-1}\right)$ was recorded from interaction of Cocker-240 at highest rate of nitrogen $\left(96 \mathrm{~kg} \mathrm{~N} \mathrm{ha}{ }^{-1}\right)$ which was not significantly different from Awasa-95 at $32 \mathrm{~kg} \mathrm{~N} \mathrm{ha}^{-1}\left(15304 \mathrm{birr} \mathrm{ha}^{-1}\right)$ and Crowford at $32 \mathrm{~kg} \mathrm{~N} \mathrm{ha}^{-1}(15103)$ while lowest GMV (12362 $\mathrm{birr} \mathrm{ha}^{-1}$ ) was obtained from variety Cocker-240 at $32 \mathrm{~kg} \mathrm{~N}$ ha $^{-1}$. Therefore, variety Awasa-95 at lower rate of nitrogen $\left(32 \mathrm{~kg} \mathrm{ha}^{-1}\right)$ could be best in intercropping system to reduce cost of fertilizer and maximize total productivity.
\end{abstract}

Keywords: Soybean,Intercropping, Land Equivalent Ratio,Gross Monetary Value

\section{Introduction}

Crop intensification is one of the strategies to increase productivity per unit area of land. For example, intercropping provides potential for the subsistence farmers who operate in low resources (inputs) situation. It is the practice of growing two or more crops simultaneously in the same field. Insurance against the vagaries of weather, disease and pests and higher productivity per unit area are the major reasons for the existence of intercropping. By growing more than one crop at a time in the same field, farmers maximize water use efficiency; maintain soil fertility, and minimize soil erosion, which are the serious drawbacks of monocropping (Francis, 1986).

In Ethiopia, as it is also true in most tropical countries, traditional cropping systems are based on resource poor farmers' subsistence requirements and are not necessarily the most efficient ones (Kidane et al., 2010). Because of this, crop production per unit land area is usually below National average. Therefore, in diversified crop production systems having production constraints, diversified options need to be assessed. 
In western Hararghe zone intercropping maize with sorghum, cereal with pulse, maize and Kchat is common. As most of people in Hararghe are based on cereal consumption, protein from pulse is very low. Evaluating the performance of soybean varieties for increasing of soil fertility under intercropping systems could help to maximize yield in the area.

Intercropping cereals and soybean is not anew practice and has been tried in a number of countries for example in Nigeria (Mueneke et al., 2007), Canada (Carruther, et al., 2000) and United States of America. In Africa, soybean is one of the leguminous crops selected for active research for instance, in Zimbabwe the maize yield was enhanced with soybean intercropping through nitrogen transferred from nitrogen fixing soybean to maize during crop development (Mudita et al., 2008). Brophy and Hiechel (1989) reported that the soybean released $10.4 \%$ of symbiotically fixed $\mathrm{N}$ in to the root zone over its growth period. Martin et al. (1991) also reported that the elevated yield and protein level observed in maize and soybean intercrop may be a consequence of Nitrogen transfer from soybean to maize.

Now a day the cost of inorganic fertilizer is increasing and the resource poor farmers are forced to use below recommended rate or null. Therefore, technologies that will reduce $\mathrm{N}$ fertilizer input by resource-poor farmers in the area are urgently needed. Nitrogen input through biological $\mathrm{N}_{2}$ fixation (BNF) by grain legumes can help to maintain soil $\mathrm{N}$ reserves as well as substitute for $\mathrm{N}$ fertilizer requirement for large crop yields. Different growth habit and maturity period soybean varieties have different nitrogen fixation ability. Since late maturing soybean varieties were able to fix more $\mathrm{N} 2$ than early and medium varieties, greater $\mathrm{N}$ contribution to any cropping system is expected through their roots, litter and harvest residues. Ogoke et al. (2003) reported that a positive $\mathrm{N}$ balance by soybean crop was reported due to the effect of increased crop duration and $\mathrm{N}$ application. Late maturing soybean varieties are, therefore, able to give higher $\mathrm{N}$ benefit compared to early and medium varieties for the improvement of the cropping systems. The objective of this experiment was to identify the appropriate combination of Soybean varieties and nitrogen fertilizer rates on yield, yield components and productivity of Soybean and Maize under intercropping at Mechara.

\section{Material and Methods}

An on station experiment was conducted for in the 2012/13 cropping season at Mechara Agricultural Research Center (MeARC) west Hararghe Zone, eastern Ethiopia. Three varieties of soybean namely; Awasa-95, Cocker-240 and Crowford and maize variety Melkesa-2 were used for the study. Awassa-95 is relatively early to intermediate maturing variety requiring around 120 days reaching physiological maturity depending on the temperature, altitude and moisture availability of the growing locations. It is suitable for production in intermediate rainfall areas. The areas receiving $500 \mathrm{~mm}$ rainfall in growing period is conducive for its production. Crowford is early maturing variety, determinate growth habit and takes 90-120 days to reach physiological maturity. It grows on soils free from excessive rain fall and at altitude ranges from $1300-1700 \mathrm{~m}$. Cocker-240 is a medium maturity class and indeterminate growth habit with a physiological maturity of 121-150 days. It best grows with altitude ranges $1300-1700 \mathrm{~m}$ and temperature $23-25^{\circ} \mathrm{C}$ (Mandafro et al., 2009).The maize variety Melkasa-2 used in this experiment is an open pollinated variety recommended for moisture stress areas that receive annual rainfall of 600-1000 $\mathrm{mm}$. It is early maturing variety that reaches physiological maturity in 130 days after emergence. It was released in 2004 by Melkasa Agricultural Research Center (MoA, 2011).

The three N levels (32 kg N/ha, $64 \mathrm{~kg} \mathrm{~N} / \mathrm{ha}$ and $96 \mathrm{~kg}$ $\mathrm{N} / \mathrm{ha}$ ) used in maize/soybean intercropping were from DAP and urea. The sole maize received $46 \mathrm{~kg} \mathrm{~N} / \mathrm{ha}$ from urea and $18 \mathrm{~kg} \mathrm{~N} /$ ha from DAP. Sole soybean varieties received $18 \mathrm{~kg}$ $\mathrm{N} /$ ha and $46 \mathrm{~kg} \mathrm{P}_{2} \mathrm{O}_{5} /$ ha from $100 \mathrm{~kg}$ DAP ha ${ }^{-1}$. The rate used for the sole crops was as recommended for production of each crop.

The intercrop of maize and soybean were in $100 \%$ of the sole maize population and $53.3 \%$ of soybean population was intercropped as additive series between the two maize rows at the same time. Two seeds per hill of both maize and soybean were planted to ensure germination and good stand of the crops and were thinned to one plant per hill after emergence. The plot size for intercropping was $11.25 \mathrm{~m}^{2}(3.75$ $\mathrm{m}$ width and $3 \mathrm{~m}$ length). The plot size for sole maize was the same as the intercropped with the row spacing of $0.75 \mathrm{~m}$ and $0.25 \mathrm{~m}$. Four rows of soybean were planted in maize rows in between plant spacing of $0.05 \mathrm{~m}$. The plot size for sole soybean was $11.25 \mathrm{~m}^{2}$ (3.75 $\mathrm{m}$ width and $3 \mathrm{~m}$ length) containing nine rows, $0.4 \mathrm{~m}$ and $0.05 \mathrm{~m}$ row spacing and spacing between plants, respectively. The yield data for experiment were collected from the net plot area of $4.5 \mathrm{~m}^{2}$ $(2.25 \mathrm{~m} \mathrm{x} 2 \mathrm{~m})$ both for sole and intercropped. The design of the experiment was randomized complete block design in factorial arrangement in three replications.

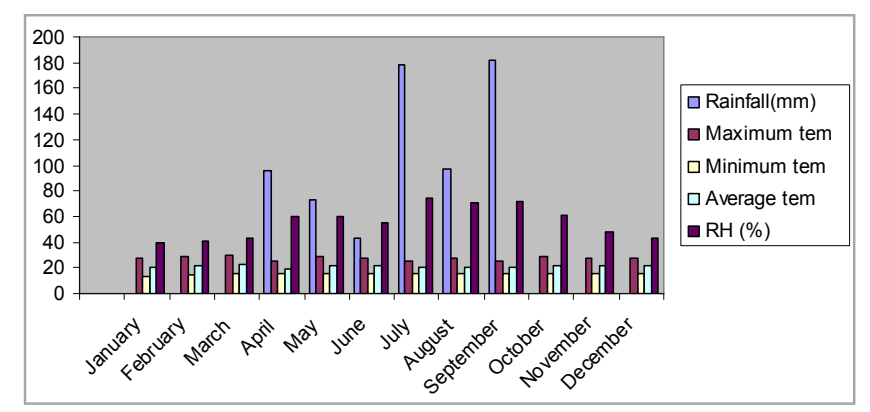

Figure 1. Weather condition of experimental area during 2012 Source: MeARC weather station, 2012.

\subsection{Soil Condition of Experimental Area}

Analysis of soil before planting was done for some physical and chemical properties of soil at Ziway Soil Laboratory of Oromia Agricultural Research Institute (Table 1). The analysis indicated that the soil had low levels of total nitrogen $(0.172 \%)$ and medium organic matter $(2.62 \%)$, 
medium level of available phosphorus (21.3ppm) and high CEC (30.32) as per the criteria developed by Murphy (1968) for Ethiopian soils and Landon (1984) for tropical soils. The $\mathrm{pH}$ of the soil was 5.82 showing moderately acidic nature of the soil (Tekalign, 1991). The textural class of the experimental site was silty clay soil.

Table 1. Selected physico-chemical properties of experimental soil.

\begin{tabular}{ll}
\hline Soil characteristic & Values \\
\hline $\mathrm{pH}\left(1: 2.5 \mathrm{H}_{2} \mathrm{O}\right)$ & 5.82 \\
Organic matter $(\%)$ & 2.62 \\
Total nitrogen $(\%)$ & 0.172 \\
Available phosphorus (ppm) & 21.3 \\
Cation exchange capacity (meq/100g) & 30.32 \\
\hline
\end{tabular}

Table 2. Total nitrogen of the experimental plot after harvest in response to the treatments.

\begin{tabular}{ll}
\hline Treatments & Total Nitrogen (\%) \\
\hline Maize +Awasa-95+32 kg N/ha & 0.073 \\
Maize +Awasa-95+64 kg N/ha & 0.099 \\
Maize +Awasa-95 +96 kg N/ha & 0.114 \\
Maize +Crowford + 32 kg N/ha & 0.071 \\
Maize +Crowford +64 kg N/ha & 0.086 \\
Maize +Crowford +96 kg N/ha & 0.099 \\
Maize +Cocker-240 + 32kg N/ha & 0.099 \\
Maize +Cocker-240 +64kg N/ha & 0.097 \\
Maize +Cocker-240+96kg N/ha & 0.085 \\
Sole maize & 0.064 \\
Sole cocker & 0.099 \\
Sole Crowford & 0.085 \\
Sole Awasa-95 & 0.099 \\
Before planting & 0.172 \\
\hline
\end{tabular}

\subsection{Post Harvest Soil Analysis}

The soil analysis for the samples collected before planting and after harvesting revealed that there was variation in total nitrogen due to variation in cropping practice (Table 2). The soil analysis after harvesting showed that intercropping of maize and soybean resulted in increased total soil nitrogen than sole maize planting. However, all cropping systems reduced total nitrogen compared to total nitrogen of the site before planting (Table 2). The reason for the reduction of total nitrogen could be due to maize and soybean depleted soil nutrients extensively and most of the soil nitrogen was removed through grains and other plant parts of both crops. Other possible losses could be through denitrification, leaching, volatilization and/or their combination. Low soil $\mathrm{pH}$ and drought might have affected nodule development and efficiency that ultimately affected the amount of atmospheric nitrogen fixed by soybean.

\subsection{Data Collected and Analysis}

Data on maize yield components such as number of ears per plant, ear length, thousand kernel weight, grain yield and soybean number of pods per plant,100 seed weight (g), grain yield $\left(\mathrm{kg} \mathrm{ha}^{-1}\right)$ and harvest index $(\%)$ were collected. The collected data were analyzed using GenStat Release 13.3 software (Genstat, 2010). Mean separation was carried out using Least Significant Difference (LSD) test at 5\% probability level.

\section{Results and Discussion}

\subsection{Maize Yield Components and Yield}

Analysis of variance showed that maize stand count at harvest was not significantly affected by main effect of soybean varieties, nitrogen rates and interaction of main effects. Stand count of maize was significantly $(p<0.05)$ affected by cropping system (Table 3 ). The mean number of stand count of sole cropped maize was higher (21.67/plot) than intercropped maize 20.11/plot (Table 3). The lower stand count in intercropped maize may be due to competition for the same resource with soybean or due to shortage of moisture during early vegetative growth. Similar to this result, Biruk (2007) reported reduction in stand count of intercropped sorghum with common bean varieties.

Table 3. Main effects of the intercropped soybean varieties and nitrogen rates on yield components of maize in maize and soybean intercropping.

\begin{tabular}{|c|c|c|c|c|c|c|}
\hline Treatments & $\begin{array}{l}\text { No. of stand } \\
\text { count/plot at harvest }\end{array}$ & No. of ears per plant & Ear length(cm) & No. of kernels per ear & $\begin{array}{l}1000 \text { kernels } \\
\text { weight }(\mathrm{g})\end{array}$ & $\begin{array}{l}\text { Harvest } \\
\text { index }(\%)\end{array}$ \\
\hline \multicolumn{7}{|c|}{ Soybean varieties } \\
\hline Awasa-95 & 20.22 & 1.044 & 11.80 & 396.6 & 219.1 & 33.9 \\
\hline Cocker-240 & 19.78 & 1.067 & 12.71 & 378.2 & 229.9 & 37.6 \\
\hline Crowford & 20.33 & 1.133 & 12.64 & 398.1 & 220.8 & 34.3 \\
\hline $\operatorname{LSD}(5 \%)$ & NS & NS & NS & NS & NS & NS \\
\hline \multicolumn{7}{|c|}{ Nitrogen rates $\left(\mathrm{kgha}^{-1}\right)$} \\
\hline 32 & 19.44 & 1.07 & 12.24 & 386.4 & 226.3 & 33.8 \\
\hline 64 & 20.67 & 1.06 & 12.60 & 396.0 & 220.4 & 37.2 \\
\hline 96 & 20.33 & 1.12 & 12.31 & 390.4 & 223.8 & 34.7 \\
\hline $\operatorname{LSD}(5 \%)$ & NS & NS & NS & NS & NS & NS \\
\hline CV $(\%)$ & 6.7 & 11.1 & 13.8 & 11.8 & 8.6 & 15.4 \\
\hline \multicolumn{7}{|c|}{ Cropping system } \\
\hline Intercropping & $20.11 b$ & $1.08 \mathrm{~b}$ & $12.39 \mathrm{~b}$ & 391.0 & $223.3 b$ & 35.3 \\
\hline Sole cropping & $21.67 \mathrm{a}$ & $1.26 \mathrm{a}$ & $14.87 \mathrm{a}$ & 428.0 & $294.0 \mathrm{a}$ & 31.7 \\
\hline $\operatorname{LSD}(5 \%)$ & 1.48 & 0.15 & 2.19 & NS & 51.97 & NS \\
\hline CV $(\%)$ & 5.8 & 10.8 & 13.9 & 10.9 & 19.1 & 16.7 \\
\hline
\end{tabular}

Means followed by the same letter(s) in the column are not significantly different at $5 \%$ level of significance

$\mathrm{NS}=$ not significant 
Number of ears per plant, ear length and number of kernels per ear were not significantly affected by main effect of soybean varieties; nitrogen rates and interaction of main effects. However, cropping system had significant effect on number of ears per plant and ear length (Table 3). Sole cropped maize produced significantly more number of ears per plant (1.26) than intercropped 1.08 (Table 3). Similarly, significantly longer ear $(14.89 \mathrm{~cm})$ was recorded due to sole cropping while shorter ear length $(12.39 \mathrm{~cm})$ scored due to intercropped maize (Table 3). The reduction in number of ears per plant and ear length in intercropped maize might be due to the reduction in the ear leaf photosynthesis due to competition with soybean that lowers the number of ears per plant. Similar to this result, Wogayehu (2005) and Walelign (2008) reported lower number of ears per plant, ear length and number of kernels per ear of maize from intercropped maize with haricot bean varieties.

Analysis of variance showed that 1000 kernel weight, grain yield and harvest index were not significantly affected by main effect of soybean varieties and nitrogen rates, while grain yield was significantly influenced by interaction of main effects (Table 3 and figure 2). The highest grain yield $\left(2196 \mathrm{~kg} \mathrm{ha}^{-1}\right)$ was obtained from combination of maize intercropped with soybean variety Crowford and $32 \mathrm{~kg} \mathrm{~N} \mathrm{ha}^{-1}$ and the lowest maize grain yield $\left(1352 \mathrm{~kg} \mathrm{ha}^{-1}\right)$ was obtained from maize intercropped with soybean variety Awasa-95 at $96 \mathrm{~kg} \mathrm{~N} \mathrm{ha}{ }^{-1}$. Higher grain yield of maize with soybean variety Crowford might be due to good nitrogen fixing abilities related to the higher number of nodules per plant as compared to other varieties, and early maturity of soybean variety Crowford. This might be because intercropping with early maturing legume could lead to increased productivity of the cereal (Rao, 1980).

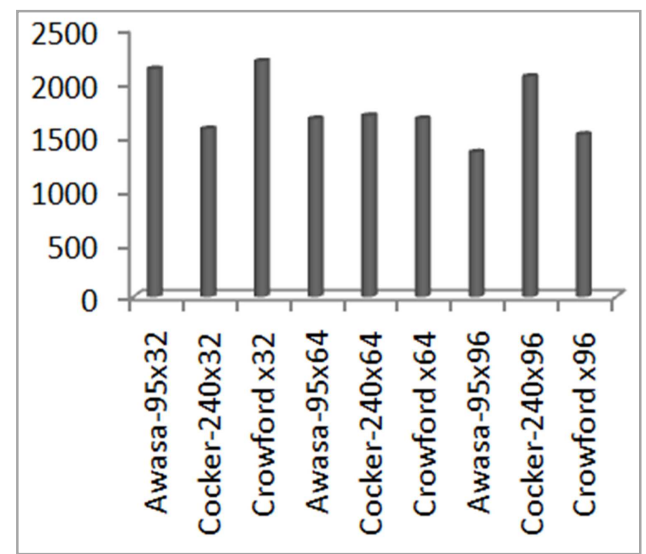

Figure 2. Interaction effect of the intercropped soybean varieties and nitrogen rate on grain yield $\left(\mathrm{kg} \mathrm{ha}^{-1}\right)$ of maize in maize and soybean intercropping.

Grain yield of maize was significantly reduced by $31.7 \%$ due to intercropping. Similarly, Wandahwa et al. (2006) found that intercropping maize and soybean reduced the yield of maize probably because of competition for resources.

Even though the difference was not significant, higher harvest index (35.3\%) was recorded from intercropped than sole cropped maize (31.7\%) (Table 3). The higher harvest index from intercropped maize could be due to increasing in nitrogen rates in intercropping increased biomass of maize. Similar result was reported by Selamawit (2007) that higher harvest index was from intercropped maize with potato than sole cropped maize.

In this study a severe water stress during early growing period in June (43.3mm) and August $(97.7 \mathrm{~mm}$ ) might have contributed for lower yield and yield components of maize.

\subsection{Soybean Yield Components and Yield}

The analysis of variance showed that number of pod per plant, 100 seed weight and harvest index were significantly $(\mathrm{P}<0.05)$ affected by soybean varieties. The highest number of pods per plant (32.22) was obtained from soybean variety Awasa-95 intercropped with maize while the lowest number of pod per plant (26.0) was obtained from variety Crowford (Table 4). Similar to this result, Thole (2007) reported that number of pods per plant of soybean intercropped with maize was significantly reduced by soybean varieties. Number of seeds per pod was not significantly affected by main effect of soybean varieties, nitrogen rates and their interaction and cropping system (Table 4). The number of 100 seed weight was significantly affected by main effect of varieties. The highest 100 seed weight $(17.31 \mathrm{~g})$ was obtained from soybean variety Crowford intercropped with maize while significantly the lowest 100 seed weight $(14.16 \mathrm{~g})$ was obtained from soybean variety Awasa-95 (Table 4). The highest 100 seed weight in variety Crowford could be due its larger seed size.

Cropping system significantly $(\mathrm{P}<0.05)$ affected 100 seed weight and grain yield. Higher 100 seed weight $(15.95 \mathrm{~g})$ was recorded from intercropping (Table 4). This could be the fact that the lower intra species competition between soybean as plant density was lower in intercropping than sole cropped soybean and higher seed weight was recorded from lower plant density (Turk et al., 2003). Similar to this result, Wogayehu (2005) in maize/haricot bean, Biruk (2007), in sorghum/haricot bean and Egbe et al. (2010) from sorghum/soybean intercropping study reported higher 100 seed weight of legume components in intercropping than in sole crop.

Grain yield per hectare of soybean was significantly affected by main effect of soybean varieties and nitrogen rates (Table 4). Yield obtained from plot treated with $96 \mathrm{~kg} \mathrm{~N}$ $\mathrm{ha}^{-1}\left(842 \mathrm{~kg} \mathrm{ha}^{-1}\right)$ was significantly higher than that of $32 \mathrm{~kg}$ $\mathrm{N} \mathrm{ha}^{-1}\left(586 \mathrm{~kg} \mathrm{ha}^{-1}\right)$. In this result, the yield of soybean was enhanced by increased level of nitrogen rates. The response of soybean to increase in grain yield might be the soil was deficit for nitrogen required by crop. In agreement with this result, Wandahwa et al. (2006) reported that the yield of soybean was increased due to increased nitrogen fertilizer in intercropped maize and soybean.

Cropping system highly significantly $(\mathrm{P}<0.01)$ affected the yield of soybean. Sole cropping gave significantly higher grain yield $\left(1754 \mathrm{~kg} \mathrm{ha}^{-1}\right)$ than intercropping $703 \mathrm{~kg} \mathrm{ha}^{-1}$ (Table 4). 
Lower grain yield of the intercropped soybean might be due to the competition effect exerted by maize component for limited growth factors in intercropping and lower stand count under intercropping. Pal et al. (2001) and Muoneke et al. (2007) reported similar yield reductions in soybean intercropped with maize and sorghum and associated the yield depression to interspecific competition and the depressive effect of the cereals.

Here in additive intercropping of maize and soybean, the intercropped soybean grain yield per hectare was reduced by $40 \%$ as compared sole cropped (Table 4). Comparably, Huxley and Maingu (1978), in cereals and legumes intercropping system, reported that the grain yield of the legume component declined, on average, by about $52 \%$ of the sole crop yield, whereas the cereal yield was reduced by only $11 \%$.

Thus, the general observation in this study showed that yields of soybean component were significantly depressed by maize component in intercropping. This is most likely due to competition for soil nutrient and the reduction in transmitted photosynthetically active radiation to the soybean as a result of shading.

The harvest index of soybean was highly significantly $(\mathrm{P}<0.01)$ affected by soybean varieties. The highest harvest index $(47 \%)$ was from soybean variety Crowford and the lowest harvest index was from Awasa-95 (32.7\%) which was significantly not different from variety Cocker-240 (36.7\%) (Table 4). The highest harvest index recorded for variety Crowford intercropped with maize might be due to the high grain yield to biomass obtained by the variety as a result of high partitioning of dry matter to the grain. Udealor (2002) and Ano (2005) reported that the differences in harvest index might be due to the inherent varietal characteristics, environmental factors and other cultural practices.

Table 4. Effect of intercropped soybean varieties and nitrogen rates on yield components and yield of soybean in maize and soybean intercropping.

\begin{tabular}{|c|c|c|c|c|c|}
\hline Treatments & No. of pods per plant & No. of seeds per pod & 100 seed weight (g) & Grain yield $\left(\mathrm{kgha}^{-1}\right)$ & Harvest index (\%) \\
\hline \multicolumn{6}{|c|}{ Soybean varieties } \\
\hline Awasa -95 & $32.22 \mathrm{a}$ & 2.49 & $14.16 \mathrm{c}$ & 679 & $32.7 b$ \\
\hline Cocker-240 & $28.56 \mathrm{abc}$ & 2.53 & $16.07 \mathrm{ab}$ & 755 & $36.7 \mathrm{~b}$ \\
\hline Crowford & $26.0 \mathrm{c}$ & 2.35 & $17.31 \mathrm{a}$ & 676 & $47.0 \mathrm{a}$ \\
\hline $\operatorname{LSD}(0.05)$ & 4.67 & NS & 1.25 & NS & 8.86 \\
\hline \multicolumn{6}{|c|}{ Nitrogen rates $\left(\mathrm{kgha}^{-1}\right)$} \\
\hline 32 & 26.33 & 2.39 & 15.73 & $586 \mathrm{~b}$ & 36.1 \\
\hline 64 & 29.67 & 2.40 & 15.87 & $681 \mathrm{ab}$ & 39.0 \\
\hline 96 & 30.78 & 2.59 & 16.23 & $842 a$ & 41.4 \\
\hline $\operatorname{LSD}(0.05)$ & NS & NS & NS & 212.5 & NS \\
\hline CV $(\%)$ & 16.2 & 10.2 & 7.9 & 30.2 & 22.8 \\
\hline \multicolumn{6}{|c|}{ Cropping system } \\
\hline Intercropping & 28.9 & 2.46 & $15.95 \mathrm{a}$ & $703 b$ & 38.8 \\
\hline Sole cropping & 31.8 & 2.54 & $14.52 \mathrm{~b}$ & $1754 a$ & 33.7 \\
\hline $\operatorname{LSD}(0.05)$ & NS & NS & 1.21 & 169.4 & NS \\
\hline CV $(\%)$ & 19.9 & 10 & 9.9 & 22.4 & 26.9 \\
\hline
\end{tabular}

Means followed by the same letter(s) within column are not significantly different at $5 \%$ level of significance NS=Not significant

Table 5. Effect of intercropped soybean varieties and nitrogen rates land equivalent ratio (LER) and gross monetary values (GMV) of maize and soybean intercropping.

\begin{tabular}{|c|c|c|c|c|c|c|}
\hline \multirow{2}{*}{$\begin{array}{l}\text { Treatments } \\
\text { Soybean varieties }\end{array}$} & \multicolumn{3}{|l|}{ LER } & \multicolumn{3}{|l|}{ MV } \\
\hline & Maize & Soybean & Total & Maize(Birr/Ha) & Soybean(Birr/ha) & GMV(Birr/ha) \\
\hline Awasa-95 & 0.70 & 0.39 & 1.09 & 8906 & 4685 & 13591 \\
\hline Cocker-240 & 0.69 & 0.40 & 1.08 & 9213 & 5208 & 14421 \\
\hline Crowford & 0.69 & 0.41 & 1.1 & 9318 & 4662 & 13980 \\
\hline $\operatorname{LSD}(0.05)$ & NS & NS & NS & NS & NS & NS \\
\hline \multicolumn{7}{|c|}{ Nitrogen rates $\left(\mathrm{kgha}^{-1}\right)$} \\
\hline 64 & 0.65 & 0.39 & 1.04 & 8694 & 4697 & 13391 \\
\hline 96 & 0.68 & 0.48 & 1.16 & 8533 & 5811 & 14344 \\
\hline $\operatorname{LSD}(0.05)$ & NS & NS & NS & NS & NS & NS \\
\hline $\mathrm{CV}(\%)$ & 17.8 & 20.7 & 16.3 & 19.9 & 38.4 & 14.7 \\
\hline \multicolumn{7}{|l|}{ Cropping system } \\
\hline Intercropping & $0.69 b$ & $0.40 \mathrm{~b}$ & $1.09 \mathrm{a}$ & $9146 b$ & $4850.7 \mathrm{~b}$ & 13996.7 \\
\hline Sole cropping & $1.0 \mathrm{a}$ & $1.0 \mathrm{a}$ & $1.0 \mathrm{a}$ & $13387 \mathrm{a}$ & $12102.6 \mathrm{a}$ & - \\
\hline CV $(\%)$ & 18.5 & 20.7 & 16.0 & 24 & 22.4 & - \\
\hline
\end{tabular}

Means followed by the same letter(s) within column are not significantly different at $5 \%$ level of significance 


\subsection{Total Land Productivity and Gross Monetary Evaluation}

Analysis of variance showed that partial LER of maize and soybean and total LER were not significantly $(\mathrm{P}<0.05)$ affected by the main effects of soybean varieties, $\mathrm{N}$ rates and their interaction. The highest total LER due to main effect of variety was obtained from soybean variety Crowford intercropped with maize (1.10) while the lowest value was obtained from Cocker (1.08). With respect to the main effect of $\mathrm{N}$, the highest LER (1.16) was obtained due to application of $96 \mathrm{~kg} \mathrm{~N} \mathrm{ha}^{-1}$ and the lowest LER (1.04) was obtained due to $64 \mathrm{~kg} \mathrm{~N} \mathrm{ha}^{-1}$ (Table 5).

Productivity was improved in almost all intercrops as depicted by LER values greater than one (Table 5). The total land productivity ranged from 108\% in Cocker-240 and maize to $110 \%$ Crowford and maize intercrop as compared to sole crops. This indicated that intercropping of maize and soybean was advantageous than sole planting of either maize or soybean. The result also indicated that the intercrops are more advantageous in efficiently utilizing land than the sole cropping of either maize or soybean and it would require $10 \%$ more land to get the same yield obtained from the intercropping system. This intercropping system resulted in the highest cumulative total yields than either of maize or soybean.

The LERs, greater than one in this experiment might have resulted from morphological differences of these two species and creating various niches for resources such as sun light, nutrients and moisture. The higher LERs in intercropping than mono-cropping were reported by Adeniyan and Ayola (2006), Bingcheng et al. (2008) and Javanmard et al. (2009).

Table 6. Gross monetary value (Birr $h \mathrm{~h}^{-1}$ ) of maize and soybean under intercropping as influenced by interaction of soybean varieties and nitrogen rates.

\begin{tabular}{llll}
\hline \multicolumn{4}{l}{ Nitrogen rates $\left(\mathbf{k g ~ h a}^{-\mathbf{1}}\right)$} \\
\hline Soybean varieties & $\mathbf{3 2}$ & $\mathbf{6 4}$ & $\mathbf{9 6}$ \\
\hline Awasa -95 & $15304 \mathrm{ab}$ & $12922 \mathrm{~b}-\mathrm{g}$ & $12548 \mathrm{~b}-\mathrm{h}$ \\
Cocker-240 & $12362 \mathrm{~b}-\mathrm{i}$ & $13584 \mathrm{~b}-\mathrm{e}$ & $17315 \mathrm{a}$ \\
Crowford & $15103 \mathrm{abc}$ & $13667 \mathrm{bcd}$ & $13168 \mathrm{~b}-\mathrm{f}$ \\
Intercropped mean & & & $13997 \mathrm{a}$ \\
Sole soybean & & $9146 \mathrm{~b}$ \\
Sole maize & & $13387 \mathrm{a}$ \\
& Soybean varieties x N rates & Cropping system \\
LSD $(0.05)$ & 3565.3 & & 1877 \\
CV $(\%)$ & 14.7 & 19.8 \\
\hline
\end{tabular}

Means followed by the same letter(s) within column and row are not significantly different at $5 \%$ level of significance

Unlike main effects of soybean varieties and $\mathrm{N}$ rates, the analysis of variance showed that the interaction significantly $(\mathrm{P}<0.05)$ affected the GMV in the intercropping system. The highest GMV (17,315 ETB ha $\left.{ }^{-1}\right)$ and the lowest (12,362 ETB $\mathrm{ha}^{-1}$ ) were obtained from soybean variety Cocker-240 intercropped with maize at $96 \mathrm{~kg} \mathrm{~N}^{-1}$ and $32 \mathrm{~kg} \mathrm{~N}^{-1}$ respectively (Table 6). This finding was in agreement with the previous studies on maize-soybean intercropping by Raji
(2007), Thole (2007) and Gani (2012) who obtained higher monetary returns from intercropping maize and soybean as compared to sole maize.

\section{Conclusion}

Due to increasing population, decreasing land units and soil fertility, integrating legumes in to the cereal production system is a viable option in western Hararghe for food security. The statistical analysis revealed that maize yield components and yield were not significantly affected by main effects of varieties and nitrogen except grain yield which was affected by interaction of main effects. The highest maize grain yield $\left(2196 \mathrm{~kg} \mathrm{ha}^{-1}\right)$ was for soybean variety Crowford at $32 \mathrm{~kg} \mathrm{~N} \mathrm{ha}^{-1}$ and the lowest yield (1352 kg ha-1) was recorded from maize intercropped with soybean variety Awasa-95 at $96 \mathrm{~kg} \mathrm{~N} \mathrm{ha}^{-1}$. The main effect of soybean variety significantly affected yield components of soybean such as number of pod per plant, 100 seed weight and harvest index while $\mathrm{N}$ and their interaction had no significant effect on yield and yield components of soybean except grain yield which was significantly influenced by main effect of nitrogen. The highest LER due to main effect of soybean varieties (1.10) was recorded from soybean variety Crowford intercropped with maize while the highest LER (1.16) due to main effect of nitrogen rates was recorded from the highest rate of nitrogen $\left(96 \mathrm{~kg} \mathrm{~N} \mathrm{ha}^{-1}\right)$ and the highest GMV (17315 Birr ha ${ }^{-1}$ ) was obtained from Cocker-240 and $96 \mathrm{~kg} \mathrm{~N} \mathrm{ha}^{-1}$ while the lowest GMV (12362 Birr ha ${ }^{-1}$ ) was from Cocker240 and $32 \mathrm{~kg} \mathrm{~N} \mathrm{ha}^{-1}$. Awasa-95at lowest rate of nitrogen (32 $\mathrm{kg} \mathrm{N} \mathrm{ha-}{ }^{1}$ ) which was not significantly different from Cocker-240 at highest rate of nitrogen $\left(96 \mathrm{~kg} \mathrm{~N} \mathrm{ha}^{-1}\right)$ could be better in intercropping system to maximize yield of both crops as well as total productivity.

\section{Ackowledgements}

The author thanks Ahmedziyad Abubaker and Wolansa Mokonin for their support in data collection and Oromia Agicultural Research Institute for financial support.

\section{References}

[1] Ano A. O, 2005. Effect of soybean relayed in to yam minisett/maize intercrop on the yield of component crops and soil fertility of yam based system. Nigeria Journal of. Soil Science, 15: 20-25.

[2] BirukTesfaye, 2007. Effects of Planting Density and Varieties of Common bean (Phaseolusvulgaris L.) Intercropped with Sorghum (Sorghum bicolor L.) on Performance of the Component Crops and Productivity of the System in South Gondar, Ethiopia. M.Sc. Thesis. Haramaya University.

[3] Brophy, L. S and G. H. Heichel, 1989. Nitrogen Release from Roots of Alfalfa and Soybean in Intercrops. Direct ${ }^{15} \mathrm{~N}$ Labeling Methods. 
[4] Carruthers K, Prithiviraj BFQ, Cloutier D, Martin RC, Smith DL, 2000. Intercropping maize with soybean, lupin and forages: yield component responses. European Journal of Agronomy, 12: 103-115.

[5] Cotteinie, A, 1980. Soil and Plant Testing as a Base of Fertilizer Recommendations. Soils Bulletins, No. 38, FAO, Rome.

[6] Egbe, O. M, Alibo, S. E and Nwueze, I., 2010. Evaluation of Some Extra-Early- And Early-Maturing Cowpea Varieties for Intercropping With Maize in Southern Guinea Savanna of Nigeria. Agriculture and Biology Journal of North America. 1(5) $845-858$.

[7] FAO, 2000. Fertilizers and Their Use $4^{\text {th }}$ ed. International Fertilizer Industry Association, FAO, Rome, Italy.

[8] Francis, C. A., 1986. Multiple cropping systems. Vol. 1. Macmillan Publishing Co., New York.

[9] Fukai, S. and B. R. Trenbath, 1993. Presses of Determining Intercrop Productivity and Yield of Component Crops. Field Crops Research, 34: 247-271.

[10] Gani, O. K., 2012. Effect of phosphorus fertilizer application on the performance of maize/soybean intercrop in the southern Guinea savanna of Nigeria. Archives of Agronomy and Soil Science, 58:2, 189-198.

[11] GenStat, 2015. GenStat Release 15, VSN International Ltd.

[12] Ghosh, P. K., 2004. Growth yield competition and economics of groundnut/cereal fodder intercropping systems in the semiarid tropics of India. Field Crops Research, 88: 227-237.

[13] Huxley, P. A. and Z. Maingu, 1978. Use of a systematic spacing design as an aid to the study of intercropping: Some general considerations. Experimental Agriculture, 14: 519-27.

[14] Kidane Georgis, 2010. Inventory of Adaptation Practices and Technologies of Ethiopia. Environment and natural resource working paper 38 , FAO, Rome.

[15] Mandefro, N., Anteneh, G., Chimdo, A., and Abebe K., (Eds.), 2009. Improved technologies and resource management for Ethiopian Agriculture. A Training Manual. RCBP, MoARD, Addis Ababa, Ethiopia.

[16] Martin, R. C., Voldeng, H. C. and Smith, D. L. 1990. Intercropping corn and soybean in a cool temperate region: yield, protein and economic benefits. Field Crops Research. 23: 295-310.

[17] MoA (Ministery of Agriculture), 2011. Crop Variety Registry, Issue Number 14, Addis Ababa.

[18] Mudita, I.I., Chiduza, S.J. Richardson-Kageler and F.S. Murangu, 2008. Performance of Maize and Soybean Cultivars of Varying Growth Habit in Intercrop in Sub humid Environments' of Zimbabwe. Journal of Agronomy, 7(3): 227237.

[19] Muoneke C.O, Ogwuche M.O, Kalu B.A., 2007. Effect of maize planting density on the performance of maize/soybean intercropping system in a guinea savanna agroecosystem. Afr. J. Agric. Res., 2: 667-677.
[20] Murphy, H.F., 1968. A report on fertility status and other data on some soils of Ethiopia. Expt. Bull. No. 44. College of Agriculture, Haile Selasie I University, Alemaya, Ethiopia. $551 \mathrm{p}$.

[21] Ogoke I.J., Carsky R.J., Togun A.O. \& Dashiell K., 2003. Effect of $\mathrm{P}$ fertilizer application on $\mathrm{N}$ balance of soybean crop in the Guinea savanna of Nigeria. Agriculture Ecosystem and Environment, 100: 153-159.

[22] Olsen, S.R., C.V. Cole., F.S. Watanabe and L.A. Dean, 1954. Estimation of Available Phosphorus in Soils by Extraction with Sodium Bicarbonate. USDA Circular, 939: 1-19.

[23] Raji, J. A., 2007. Intercropping soybean and maize in a derived savanna ecology. African Journal of Biotechnology. 6 (16): $1885-1887$.

[24] Selamawit Getachew., 2007.Effect of Plant Population and Nitrogen Fertilizer on Growth and Yield of Intercropped Potato (Solanumtuberosum L.) and Maize (Zea mays L.) at Haramaya, Eastern Ethiopia. M.Sc. Thesis, Haramaya University.

[25] Tekelign Tadesse, 1991. Soil, Plant, Water, Fertilizer, Animal Manure and Compost Analysis. Working Document No. 13. International livestock Research center for Africa (ILCA), Addis Ababa.

[26] Thole, A., 2007. Adaptability of soybean varieties to intercropping under leaf stripped and detasseled maize. MSc Thesis. University of Zimbabwe.

[27] Turk M.A., A.M. Tawaha and M.K.J. El-Shatnawi, 2003. Response of Lentil (Lens culinarismedic) to plant density, sowing date, phosphorus fertilization and ethephonapplication in the absence of moisture stress. Journal of Agronomy and Crop Sciences, 189: 1-6.

[28] Udealor A., 2002. Studies on the growth, yield, organic matter turnover and soil nutrient changes in cassava (Manihotesculenta Crantz)/vegetable cowpea (Vignaunguiculata L. Walp.) mixtures. Ph. D. Dissertation, University of Nigeria, Nsukka, Nigeria.

[29] Walelign Worku., 2008. Evaluation of haricot bean (Phaseolus vulgaris L) Genotypes of diverse growth under sole and intercropping with maize in southern Ethiopia. Journal of Agronomy, 7(4): 306-313.

[30] Walkley, A and I.A. Black, 1934. An Examination of Digestion of Degrjareff Method for Determining Soil Organic Matter and Proposed Modification of the Chromic Acid Titration Method. Soil Science, 37: 29-38.

[31] Wandahwa P, Tabu IM, Kendagor MK, Rota IA. 2006. Effect of intercropping and fertilizer type on growth and yield of soybeans. Journal of Agronomy. 5(1): 69-73.

[32] Willey, R.W., 1979. Intercropping-its importance and research needs. Competition and yield advantages. Field Crops Research, 32: 1-10.

[33] Wogayehu Worku., 2005. Evaluation of Common Bean (Phaseolus vulgaris L.) Varieties Intercropped with Maize (Zea mays L.) for Double Cropping at Alemaya and Hirna areas, Eastern Ethiopia. M.Sc. Thesis. Haramaya University. 